Jurnal Abdidas Volume 2 Nomor 6 Tahun 2021 Halaman 1368 - 1373

JURNAL ABDIDAS

http://abdidas.org/index.php/abdidas

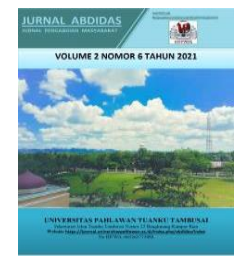

\title{
Pelatihan Pembuatan Video Pembelajaran Menggunakan Power Point bagi Pendidik dan Tenaga Kependidikan SD Muhammadiyah 3 "Ikrom" Wage Sidoarjo
}

\author{
Budi Tri Cahyono ${ }^{1 凶}$, Wahyu Nugroho ${ }^{2}$ \\ Universitas Sebelas Maret, Indonesia ${ }^{1}$ \\ BP PAUD dan DIKMAS Jawa Timur, Indonesia ${ }^{2}$ \\ E-mail: buditricahyono@staff.uns.ac.id ${ }^{1}{ }^{\text {cakwahyukumis@gmail.com }}{ }^{2}$
}

\begin{abstract}
Abstrak
Perkembangan teknologi dan informasi pada masa pandemi Covid-19 mengharuskan pendidik dalam proses pembelajaran dengan memanfaatkan teknologi komputer. Siswa diharapkan dapat memperoleh informasi dari berbagai sumber termasuk dari guru, sehingga guru dituntut untuk dapat membimbing siswa mampu memperoleh informasi dengan baik. Informasi yang diperoleh siswa dalam pembelajar diantaranya adalah pengetahuan. Pengetahuan yang berupa logika dan fisik tidak dapat ditransfer secara utuh dari pikiran guru kepikiran siswa. Penggunaan media pembelajaran power point interaktif untuk membuat media pembelajaran video masih belum dimaksimalkan oleh pendidik dan tenaga kependidikan di lingkungan Perguruan Muhammadiyah Ranting Wage, Pengabdian masyarakat ini dilakukan untuk meningkatkan kemampuan guru untuk membuat video pembelajaran bagi kebutuhan siswa didiknya. Pelatihan ini diikuti oleh 20 guru SDN Muhammadiyah 3 "Ïkrom" Wage Sidoarjo dengan materi pembuatan video pembelajaran menggunakan power point, ketika selesai pelatihan diadakan evaluasi, dan diberikan pendampingan untuk melihat penerapan dan ketercapaian dari pelatihan dalam pembuatan media pembelajaran.
\end{abstract}

Kata kunci: media pembelajaran, power point interaktif, video

\section{Abstract}

The development of technology and information during the Covid-19 pandemic requires educators in the learning process by utilizing computer technology. Students are expected to be able to obtain information from various sources including from teachers, so teachers are required to be able to guide students to be able to obtain information properly. Information obtained by students in learning includes knowledge. Knowledge in the form of logic and physics cannot be transferred completely from the teacher's mind to the student's mind. The use of interactive power point learning media to create video learning media is still not maximized by educators and education staff in the Muhammadiyah Branch Wage College environment. This community service is carried out to improve the ability of teachers to make learning videos for the needs of their students. This training was attended by 20 teachers of SDN Muhammadiyah 3 "Ïkrom" Wage Sidoarjo with material for making learning videos using power point. When the training was finished, an evaluation was held, and they were given assistance to see the implementation and achievements of the training in making learning media.

Keywords: learning media, interactive power point, video

Copyright (c) 2021 Budi Tri Cahyono, Wahyu Nugroho

$\triangle$ Corresponding author

Address : Universitas Sebelas Maret

ISSN 2721-9224 (Media Cetak)

Email : buditricahyono@staff.uns.ac.id

ISSN 2721- 9216 (Media Online)

DOI : https://doi.org/10.31004/abdidas.v2i6.485 
1369 Pelatihan Pembuatan Video Pembelajaran Menggunakan Power Point Bagi Pendidik dan Tenaga Kependidikan SD Muhammadiyah 3 Ikrom Wage Sidoarjo - Budi Tri Cahyono, Wahyu Nugroho DOI: https://doi.org/10.31004/abdidas.v2i6.485

\section{PENDAHULUAN}

Salah satu faktor rendahnya mutu pendidikan disebabkan oleh proses pembelajaran yang masih sederhana dengan menggunakan media yang tidak bervariatif. Selain itu belum diterapkannya media pembelajaran yang dapat meningkatkan penyerapan informasi dalam ingatan dengan baik. Salah satu cara untuk menyimpan informasi didalam ingatan diperlukan media pembelajaran yang tepat.

Dimana selama ini proses belajar yang tidak menggunakan media yang bervariatif, sehingga masih terdapat beberapa guru yang menggunakan metode ceramah sehingga berpengaruh terhadap rendahnya kemamupuan siswa untuk mengingat dan memahami materi. Pendidikan memiliki arti yang sangat penting dalam pembaharuan dan perkembangan masyarakat yang menyeluruh, karena dalam menghadapi perkembangan jaman dan perubahan teknologi dibutuhkan sumber daya manusia yang cerdas dan berkualitas (Amalia, 2020).

Salah satu bagian terpenting dalam proses pendidikan adalah kegiatan belajar mengajar. Proses belajar mengajar merupakan totalitas aktivitas belajar mengajar yang diawali dengan perencanaan dan diakhiri dengan evaluasi, dari evaluasi diteruskan secara follow up (Rohani, 2004), proses adalah interaksi semua atau unsur yang terdapat dalam belajar mengajar yang saling berhubungan satu dengan yang lain. Ada beberapa komponen belajar antara lain; tujuan instruksional yang hendak dicapai, materi pembelajaran, metode mengajar, alat peraga pengajaran dan evaluasi sebagai alat ukur tercapai tidaknya tujuan.
Penggunaan media yang tepat sangat diperlukan dalam pembelajaran. Penggunaan media dapat membangkitkan minat atau rasa ingin tahu yang baru dan juga diharapkan mampu membantu keefektifan penyampaian pesan dan tujuan pembelajaran (Arsyad, A. 2002.).

Tujuan dari pelatihan ini adalah meningkatkan kemampuan guru dalam mempersiapkan perencanaan pembelajaran mulai dari perancangan, penyusunan, mendesain sampai dengan menyajikan materi ke siswa dengan metode demonstrasi, diskusi, dengan metode yang tepat pendidik dapat mengenali karakteristik siswa.

Permasalahan yang sering dihadapi pendidik yaitu kurang menguasai materi pembelajaran, kurang kreatif dan inovatif dalam mengajar, kurangnya kesiapan dalam mengajar sehingga pemenuhan materi kepada siswa kurang maksimal (Astini, 2020). Akhirnya yang terjadi siswa merasa bosan karena menggunakan metode ceramah/cerita, materi yang disampaikan tidak dipahami oleh siswa, kelelahan guru yang berakibat guru tidak bergairah dalam penyampaian bahan ajar, sarana pembelajaran untuk membantu murid menyelesaikan tugas dan belajar. Sebagai fasilitator utama di kelas, guru sangat berperan untuk membuat media pembelajaran yang inovatif dan kreatif sehingga menarik siswa untuk lebih memperhatikan proses pembelajaran.

Tujuan pelatihan ini mengembangkan wawasan dalam pembuatan media pembelajaran video melalui animasi power point yang menarik dengan cara mudah guru diharapkan dapat menyesuaikan dengan materi yang akan diajarkan dan diharapkan menjadi pemicu minat siswa untuk 
1370 Pelatihan Pembuatan Video Pembelajaran Menggunakan Power Point Bagi Pendidik dan Tenaga Kependidikan SD Muhammadiyah 3 Ikrom Wage Sidoarjo - Budi Tri Cahyono, Wahyu Nugroho DOI: https://doi.org/10.31004/abdidas.v2i6.485

mengikuti pembelajaran, yang akhirnya akan meningkatkan kualitas pembelajaran di kelas (Mustofa 2007).

Target yang ingin dicapai dari pelatihan pembuatan video pembelajaran menggunakan power point sebagai berikut:

1. Terbangunnya kebiasaan pembelajaran dengan memanfaatkan teknologi informasi video dengan menggunakan power point;

2. Guru di lingkungan SD Muhammadiyah 3 "Ikrom" Wage dapat mengembangkan kreatifitas dalam mengemas pembelajaran menggunakan multimedia interaktif yang menarik dalam menyajikan pelajaran melalui media pembelajaran yang dibuat dan dikemas sesuai dengan mata pelajaran yang diampu;

3. Meningkatkan kompetensi pengajaran guru SD Muhammadiyah 3 "Ikrom” Wage Sidoarjo.

\section{METODE}

Pelaksanaan pengabdian masyarakat ini diawali dengan mengajukan usulan pelatihan ke Yayasan Muhammadiyah Ranting Wage melalui SD Muhammadiyah 3 "Ikrom" Wage Sidoarjo. Dengan waktu 3 hari menggunakan tiga tahap yang diterapkan dalam pelatihan ini, yaitu tahap presentasi, tahap demonstrasi, dan tahap pendampingan.

\section{Tahap Presentasi}

Tahap presentasi dilakukan untuk memberikan pemahaman awal bagi guru, mulai dari perancangan, penyusunan, mendesain sampai dengan menyajikan materi ke siswa, kemanfaataannya, dan penerapannya dalam pembuatan media pembelajaran interaktif.

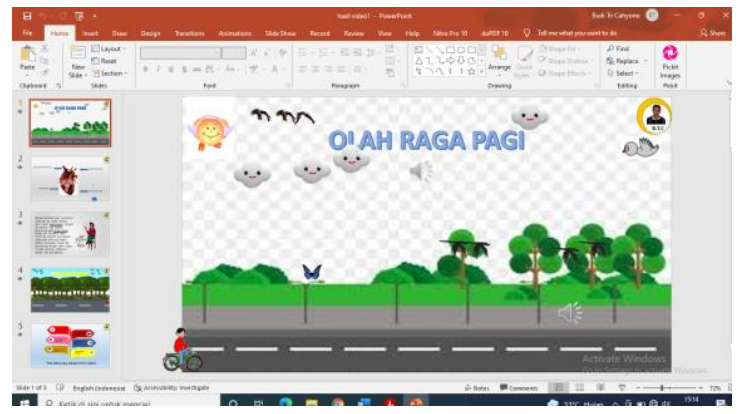

Gambar 1. Awal Pembuatan Video Pembelajaran

\section{Tahap Demonstrasi}

Tahap demonstrasi yaitu diawali dengan mendownload aset-aset yang tidak berbayar dari internet, dimana guru - guru mempraktikkan secara langsung dari arahan narasumber dalam pembuatan media pembelajaran sesuai mata pelajaran masingmasing dengan pemanfaatan program Microsoft power point.

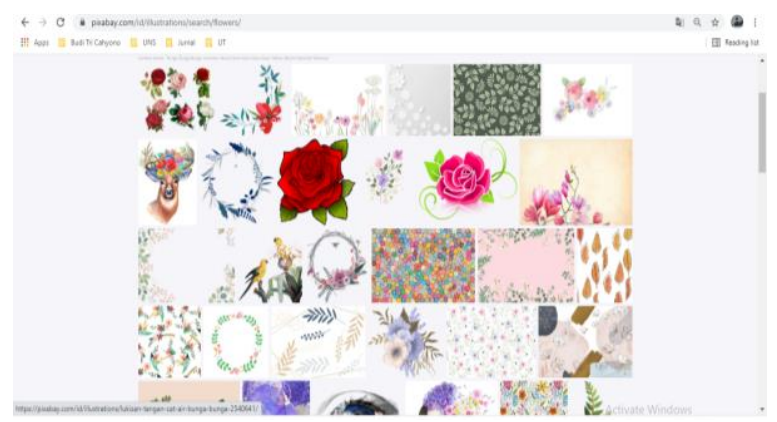

Gambar 2. Pencarian Asset yang Digunakan dalam Pembuatan Media Pembelajaran

\section{Tahap Pendampingan}

Tahap yang terakhir adalah mendampingi guruguru menerapkan pembuatan media pembelajaran sesuai dengan materi yang diampu oleh guru masing-masing sampai menjadi sebuah video pembelajaran. Para guru dapat langsung berdiskusi dengan para pemateri secara langsung untuk memahamkan materi dan 
1371 Pelatihan Pembuatan Video Pembelajaran Menggunakan Power Point Bagi Pendidik dan Tenaga Kependidikan SD Muhammadiyah 3 Ikrom Wage Sidoarjo - Budi Tri Cahyono, Wahyu Nugroho

DOI: https://doi.org/10.31004/abdidas.v2i6.485

sharing pengalaman terkait dengan masalah yang tengah dibahas dalam materi bersangkutan.

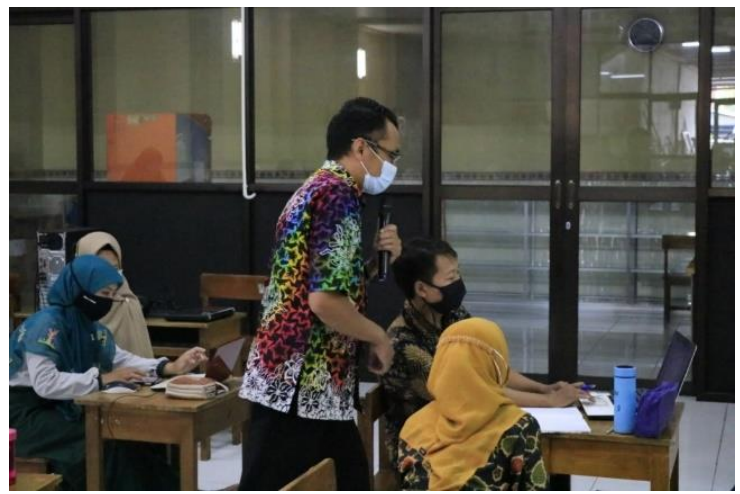

Gambar 3. Mendampingi Guru Membuat Media Pembelajaran

Dari media pembelajaran yang dibuat oleh guru-guru narasumber meminta beberapa guru untuk mempresentasikan hasil yang sudah dibuat, Narasumber mendampingi, memandu dan mengarahkan serta memberikan solusi apabila timbul permasalahan selama penugasan praktik.

\section{HASIL DAN PEMBAHASAN}

Hasil dari pelatihan adalah sebuah video pembelajaran sesuai dengan mata pelajaran yang diampu oleh masing-masing guru. Disini terjadi peningkatan kompetensi dan kemampuan guru dalam membuat materi ajar, secara umum para peserta telah mengetahui dasar-dasar Microsoft Powerpoint dan telah mampu menerapkannya. Pelatihan ini memfokuskan materi-materi di sekolah dasar dengan upaya mengembangkan media pembelajaran interaktif agar pembelajaran yang diberikan oleh guru menjadi lebih atraktif sehingga meningkatkan minat dan kualitas belajar siswa. Materi yang disajikan oleh narasumber dapat diterima, dicerna, dan dipahami peserta dengan baik. Microsoft powerpoint digunakan untuk mengembangkan media pembelajaran, dikarenakan program powerpoint ini sudah sangat akrab digunakan dalam pendidikan, sehingga guru tidak mengalami kesulitan dalam menerapkannya dan dapat mengembangkannya kembali pada materi lainnya. Microsoft Powerpoint merupakan salah satu program komputer yang dikembangkan oleh microsoft office yang digunakan untuk menyusun sebuah persentasi. Powerpoint merupakan media presentasi yang berbentuk kumpulan slide-slide yang dapat berisi teks, objek, grafik, animasi.

Hal ini didukung pula dengan kemampuan peserta di bidang komputer telah cukup memadai karena pada proses perekrutan telah ditetapkan standar minimal peserta harus telah menguasai komputer dasar sehingga pelatihan dapat berjalan lancer dan para peserta dapat berkomunikasi dengan narasumber dan peserta lain dengan lebih baik. Selanjutnya berdasar hasil praktik juga dapat dilihat bahwa para guru mampu mengetahui manfaat program Microsoft powerpoint untuk membuat media pembelajaran berbentuk video. Berdasarkan hasil karya media yang dibuat para guru, narasumber memberikan penilaian yang tersaji di table 1 . Dari table 1 menunjukkan bahwa guru yang memperoleh nilai $\mathrm{A}$ adalah guru muda berumur dibawah 40 tahun dan terbiasa menggunakan power point, guru yang memperoleh nilai B adalah guru yang berumur dibawah 50 tahun tetapi jarang menggunakan power point sebagai media pembelajaran, sedangkan yang 
1372 Pelatihan Pembuatan Video Pembelajaran Menggunakan Power Point Bagi Pendidik dan Tenaga Kependidikan SD Muhammadiyah 3 Ikrom Wage Sidoarjo - Budi Tri Cahyono, Wahyu Nugroho DOI: https://doi.org/10.31004/abdidas.v2i6.485

berumur 50 tahun ke atas mendapatkan nilai $\mathrm{C}$ karena mengenal power point ketika saat pelatihan.

Tabel 1. Nilai Akhir Pembuatan Video

Pembelajaran dengan Power Point

\begin{tabular}{|c|c|c|c|c|c|c|c|}
\hline \multirow{2}{*}{ No } & \multirow{2}{*}{ Nama } & \multicolumn{4}{|c|}{ Materi } & \multirow{2}{*}{$\begin{array}{l}\text { Rata } \\
\text { Rata }\end{array}$} & \multirow[t]{2}{*}{ Nilai } \\
\hline & & 1 & 2 & 3 & 4 & & \\
\hline 1 & Nur Khofifah & 4 & 3 & 4 & 4 & 3,75 & A \\
\hline 2 & MUHAJIR & 2 & 2 & 3 & 3 & 2,5 & $\mathrm{C}$ \\
\hline 3 & Kihajar Prastiyo & 4 & 3 & 3 & 4 & 3,5 & $\mathrm{~B}$ \\
\hline 4 & Dian Tri Anista & 4 & 3 & 3 & 3 & 3,25 & $\mathrm{~B}$ \\
\hline 5 & Dyta Pratikna & 4 & 4 & 4 & 4 & 4 & $\mathrm{~A}$ \\
\hline 6 & Eli Rahmawati & 4 & 4 & 4 & 4 & 4 & $\mathrm{~A}$ \\
\hline 7 & Muhammad Nasikin & 4 & 4 & 4 & 4 & 4 & A \\
\hline 8 & Winarti & 4 & 4 & 4 & 4 & 4 & $\mathrm{~A}$ \\
\hline 9 & Elvira Bunga $\mathrm{P}$ & 4 & 3 & 4 & 3 & 3,5 & $\mathrm{~B}$ \\
\hline 10 & INDAH NOVITA & 4 & 4 & 3 & 3 & 3,5 & $\mathrm{~B}$ \\
\hline 11 & Novi Indriani & 4 & 4 & 4 & 3 & 3,75 & $\mathrm{~A}$ \\
\hline 12 & Dwi Ernawati & 4 & 3 & 4 & 3 & 3,5 & $\mathrm{~B}$ \\
\hline 13 & Yuni Rahmawati & 4 & 4 & 4 & 4 & 4 & A \\
\hline 14 & Diah Kartikawati & 4 & 4 & 4 & 3 & 3,75 & $\mathrm{~A}$ \\
\hline 15 & Arifatu Rosyida & 4 & 4 & 4 & 3 & 3,75 & $\mathrm{~A}$ \\
\hline 16 & Ika Fitria & 4 & 4 & 3 & 4 & 3,75 & $\mathrm{~A}$ \\
\hline 17 & Ika Hidayatul M & 4 & 4 & 3 & 3 & 3,5 & $\mathrm{~B}$ \\
\hline 18 & Suryani & 4 & 3 & 4 & 3 & 3,5 & $\mathrm{~B}$ \\
\hline 19 & Yuni Khosnol k & 4 & 3 & 4 & 4 & 3,75 & A \\
\hline 20 & Nisa Izzah & 4 & 4 & 4 & 3 & 3,75 & A \\
\hline
\end{tabular}

Keterangan:

1 Membuka Power Point

2 Mencari Asset

3 Membuat Materi

4 Membuat Video

\section{SIMPULAN}

Berdasar hasil pelaksanaan kegiatan pengabdian kepada masyarakat ini dan uraian pembahasan di atas, dapat disimpulkan beberapa hal sebagai berikut ini.

1. Pemanfaatan power point untuk membuat video pembelajaran interaktif dapat mewujudkan proses pembelajaran yang menarik dan menyenangkan sesuai tujuan pembelajaran, yang pada akhirnya dapat memberikan pengaruh positif terhadap peningkatan kemampuan khususnya peserta didik.

2. Proses pembelajaran dengan menggunakan video pembelajaran interaktif merupakan salah satu alternatif yang dapat meningkatkan kemampuan peserta didik dalam memahami pelajaran tentang konsep suatu materi

3. Materi yang disajikan dapat diterima, dicerna, dan dipahami peserta dengan baik.

\section{Saran}

a. Hendaknya pelatihan yang melibatkan guru dalam pemanfataan teknologi informasi dan pembuatan media pembelajaran interaktif dapat terus berlanjut sehingga lebih banyak lagi sekolah yang dapat merasakan manfaatnya.

b. Para guru peserta pelatihan diharapkan dapat ikut aktif berperan dalam meningkatkan kualitas pembelajaran di sekolah masing masing dan menularkan ilmu yang diperoleh kepada guru-guru lain di sekolah mereka.

c. pelatihan ini dapat berpeluang untuk dijadikan ruang pengabdian dan pelatihan bagi guru untuk membuat media pembelajaran serupa dengan materi yang berbeda.

\section{DAFTAR PUSTAKA}

Amalia, I. 2020. Menggunakan Teknologi Informasi Dan Komunikasi (TIK) Dalam Proses Pembelajaran Di Sekolah Dasar. Jurnal Pendidikan dan Konseling (JPDK), 2(1), 36-39.

Arsyad, A. 2002. Media Pembelajaran. PT Raja Grafindo Persada: Jakarta.

Astini, N. K. S. 2020. Pemanfaatan Teknologi Informasi dalam Pembelajaran Tingkat 
1373 Pelatihan Pembuatan Video Pembelajaran Menggunakan Power Point Bagi Pendidik dan Tenaga Kependidikan SD Muhammadiyah 3 Ikrom Wage Sidoarjo - Budi Tri Cahyono, Wahyu Nugroho DOI: https://doi.org/10.31004/abdidas.v2i6.485

Sekolah Dasar pada Masa Pandemi Covid19. Lampuhyang, 11(2), 13-25.

Hasanah, N. 2020. Pelatihan Penggunaan Aplikasi Microsoft Power Point Sebagai Media Pembelajaran pada Guru SD Negeri 050763 Gebang. Jurnal Pengabdian Kepada Masyarakat, 1(2), 34-41.

Huda, Miftahul. 2014. Model-model Pengajaran dan Pembelajaran: Isu-isu Metodis Dan Paradigmatis. Yogyakarta: Pustaka Pelajar.

Kamil, Mustofa. 2007. Model Pendidikan dan Pelatihan. Bandung: Alfabeta

Rohani, A. 2004. Pengelolaan Pengajaran. Jakarta: PT. Rineka Cipta

Rusman. 2013. Model-model Pembelajaran Mengembangkan Profesionalisme Guru. Jakarta: Rajawali Pers.

Sardiman.2016. Interaksi dan Motivasi Belajar Mengajar. Jakarta: PT Rajawali Pers. 